\title{
BUSINESS CYCLE AND STABILITY OF CHINA'S FINANCIAL AND MONETARY SYSTEM
}

\author{
WILLIAM HONGSONG WANG* \\ ANTONIO VEGAS GARCÍA**
}

Fecha de aceptación: 27 de septiembre de 2016

Fecha de recepción: 12 de febrero de 2017

Resumen: La importancia de la economía china junto con la reciente inestabilidad del sistema financiero de China, preocupan al resto del mundo. Este artículo usa la Teoría Austriaca del Ciclo Económico para identificar los riesgos potenciales de la economía de China. En este artículo realizaremos un análisis sectorial, enfocado en el sistema monetario y financiero de China, el sector de la construcción, la industria marítima y, en especial, las empresas estatales de dichos sectores. Concluimos que el actual sistema de banca central en China está dañando a su economía y proponemos soluciones desde la perspectiva de la praxeología y la Escuela Austriaca de Economía.

Palabras clave: Teoría austriaca del ciclo económico, sistema bancario chino, economía china.

Abstract: The importance of China's economy and the instability of China's financial system are in the spotlight recently. This paper uses Austrian Business Cycle Theory to gauge the potential risks of China's economy. The approach of this paper is a sector analysis, focusing on China's monetary and financial system, shipping industry, and real estate industry, especially the state-owned enterprises in those sectors. We conclude that China's central banking system is hurting China's economy and we also propose reforms to overhaul the sys-

* Máster en Economía de la Escuela Austriaca. Doctorando en historia monetaria de China en la Universidad Complutense de Madrid. Actualmente es Director de Shalom Institute of China, think thank libertario chino. Email: williamking001@hotmail. com

** BBVA Research. Economista y máster en finanzas. Sus investigaciones se centran en el estudio de la transformación económica y financiera de China, así como en los aspectos filosóficos e históricos de China. Email: avegas76@yahoo.es 
tem, according to the perspective of praxeology and Austrian School Economics.

Keywords: Austrian Business Cycle Theory, China's banking system, China's economy.

JEL Classification: B53, D8, E310, E32, E52, H12, N15, N27, N45, N65, O53, P11, R3, R4, Y10.

\section{I \\ INTRODUCTION}

There is broad consensus among historians that from the $5^{\text {th }}$ to the $15^{\text {th }}$ centuries, China was the most advanced civilization in the world (with $32 \%$ of global GDP and $36 \%$ of the population). However, China lost importance due to the isolation that prevented China from participating in the process of industrial revolution. China reopened to the world after the Opium War in 1840. In the previous two-thousand-years of Chinese history, China had less frequency of inflation, because of free banking system with silver standard ${ }^{1}$. However, in 1928, China built its first central bank. Later on, inflation and economic crisis happened more frequently than before. After the Communist Revolution in 1949, China started to isolate once again from the western world until 1978.

Since the new reopening of China in 1978, China's economy grew significantly and connected tighter with global economy. As the second largest economy, any economic and financial fluctuation could affect the world economy to some extent. In this context, the nagging doubts about the strength of China's economy and the financial distress events during the summer of 2015, put China's economy in spotlight. Against this backdrop, this paper is an attempt to gauge the degree of stability and strength of China's economy, by using the framework of Austrian Business Cycle Theory $(\mathrm{ABCT})^{2}$, along with the recent evidence of real economy and finan-

\footnotetext{
${ }^{1}$ See J. Zhu (2012), pp 12-31.

2 See Huerta de Soto (2012), pp.167-254.
} 
cial conditions. Specifically, we will focus on the effect that China's Monetary and Financial System (CMFS) has on China's economy.

This article is divided into four chapters. In Chapter 1, we include an overview of CMFS, with the purpose of analysing core financial risk indicators according to $\mathrm{ABCT}$ framework, so as to achieve insights on the financial strength of China's Monetary System (CMS) and China's Financial System (CFS). In Chapter 2, we will discuss the effect of CMFS on China's Shipping Industry (CSI). Due to the impact of monetary easing policy, China's Shipping Industry (CSI) suffered great depression and bankruptcies, especially state-owned enterprises (SOEs). Chapter 3 is dedicated to analyse the effects on China's Real Estate Industry (CREI), which is a sector with significant oversupply problems and it is at the core of the concerns on China's economy. In Chapter 4, we will give some suggestions on how to reform the current system.

II

CHINA'S MONETARY SYSTEM AND FINANCIAL SYSTEM

In this chapter, we consider that CMS and CFS are the cornerstones of the main economic problems, and it is one of the main unreformed sectors of China's economy. Paradoxically, although China registered an ambitious economic reform after 1978, CFS experienced no significant reforms, and it is still subject to the rules of Communist Party of China (CPC). Therefore, the industry is still restricted to foreign investors and customers in comparison with western financial systems.

China's financial system is controlled by government, where political criteria outweighs profitability criteria. China's capital market is not accessible to foreign investors: they can only invest in China's companies through the interconnection of the Hong Kong markets with Shenzhen and Shanghai.

CMS and CFS, closely related with the stability of China's economy, also have an indirect but significant influence on the world economy. For this reason, we start our analysis of China's economy by the monetary and financial part. In this chapter, we analyse: (i) the overview and structure of CMS; (ii) the overview and structure 
of CFS; (iii) the foreseeable effects on China's economy according to $\mathrm{ABCT}$.

\section{Overview and Structure of China's Monetary System}

CMS is based on three pillars: a fixed exchange rate, an autonomous monetary policy, and capital controls. Capitals controls are crucial to maintain the target exchange rate, amid the autonomy of China's monetary policy. We analyse each of the three pillars.

The history of the exchange rate policy has four different periods (see Figure 1.1). In the $1^{\text {st }}$ period (1989-1994), a sharp devaluation $(134 \%)$ of RMB (renminbi) was registered. Before that, the official exchange rate was not realistic, and the government decided to narrow the gap between the «official» and «black market» exchange rate. The $2^{\text {nd }}$ period (1995-2005) was characterized by ten years with fixed exchange rate, offering stability to foreign investors and fostering Chinese exports. In the $3^{\text {rd }}$ period (2005-2013), China revalued its currency by $2 \%$ against USD and moved to a «managed floating exchange rate regime concerning a basket of currencies». The $4^{\text {th }}$ period (2013 and mid-2016) started with a new devaluation process, amid doubts on China's financial stability.

FIGURE 1.1

THE EXCHANGE RATE HISTORY OF RMB

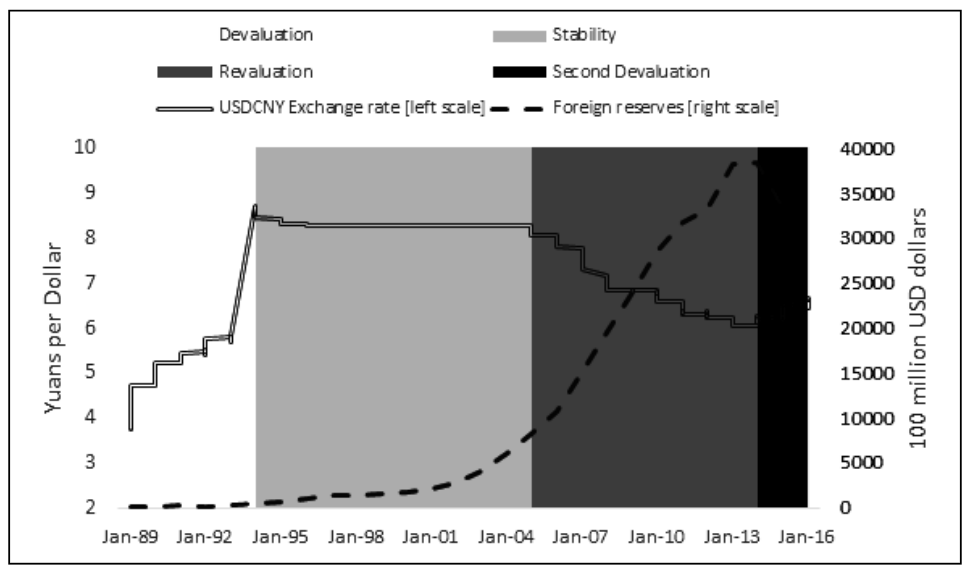

Source: Bloomberg and People's Bank of China (PBOC) 
Given that China's government sets the exchange rate, PBOC (People's Bank of China) has to intervene in market regularly (by buying or selling assets denominated in USD with RMB) affecting either demand or supply, to achieve the targeted exchange rate. This policy requires a significant proportion of foreign reserves to be able to intervene in the market as needed to achieve the exchange rate.

Under this scheme, a method to assess whether the exchange rate was undervalued or overvalued is to analyse the relationship between exchange rate and the variation in foreign reserves. If the central bank increases (decreases) its foreign reserves, it suggests that it is buying (selling) in a large-scale foreign currency by offering (demanding) RMB. Hence, the massive increases in foreign exchange reserves of PBOC (since 1993 to 2013) points that the fixed exchange rate set by China's officials was undervalued. A significant amount of RMB was created to shore up a lower exchange rate than the rate that would have prevailed without governmental intervention; these RMB were used to demand dollars (buying US government debt).

Nonetheless, such a sharp increase in RMB would create a significant inflation. For this reason, PBOC designed a «sterilization policy», which consists in issuing bonds in the domestic market, thereby eliminating the circulation of the new RMB issued previously. In this process, PBOC influences the foreign market with no inflation pressure. Nonetheless, the new undervalued exchange rate would subsidize Chinese exporters and would damage Chinese importers, as well as reducing the purchasing power of RMB. Although China moved from an unrealistic fixed exchange rate to a more market-oriented and flexible exchange rate, the exchange rate policy is still far from a free market. China's government still manage the exchange rate, along with strict capital controls.

Furthermore, China maintains an independent monetary policy, allowing for direct changes in either the amount of money or interest rates, without being subject to any other variable. PBOC has traditionally focused on the quantity of money rather than in the interest rates because banking interest rates are regulated by the government ${ }^{3}$.

\footnotetext{
${ }^{3}$ Lam, Britney and Le Cornu (2015).
} 
To manage exchange rate with an independent monetary policy requires strict capital controls in the country, because the free movement of capital would create difficulties to achieve the goals of China's monetary policy. For this reason, the liberalization of trade during China's opening and reform has not been accompanied with the liberalization of capital flows.

Capital flows can be restricted through administrative controls (prohibition of money transfers or setting maximum limits) and indirect controls (discourage or make costly capital movements). In China, both methods are used. There is an explicit prohibition for foreign companies to invest in core industries ${ }^{4}$ (telecommunication, transportation, energy and national defence). In China, capital control restrictions are focused in the following aspects: capital market securities, market maker instruments, collective investment securities, derivatives and other instruments, commercial credits, guaranteed securities, direct investments, liquidation of direct investments, real estate transactions, personal capital movements, provision for commercial banks and institutional investors, and dual exchange rate agreements.

\section{Overview and Structure of China's Financial System}

Before we deepen in the details of CFS, it is important to advert that it is profoundly opaque, complex, with a strong governmental regulation and with a low (although increasing) connection with the international financial system ${ }^{5}$. In general, the development of China's capital market is underdeveloped in comparison with western countries.

The main characteristic of CFS is the high proportion of banking credit in the total capital (see Figure 1.2), although this proportion decreased over time. In 2006, $76 \%$ of total credit was in the banks' balance sheet, while in 2014 it was $61 \%$. The rest of the credit was in the bond market and in China's Shadow Banking (CSB), which we will analyse later.

\footnotetext{
${ }^{4}$ F. Xiao and Kimball (2005).

${ }^{5}$ J. Dong and A. Neut (2016).
} 
Moreover, the banking credit is hugely concentrated: only five State-Owned Banks (SOB's) manage the 33\% of China's total cred$\mathrm{it}^{6}$, thereby indicating that SOBs are the main players in CFS. Thus, we will start our analysis with SOBs.

FIGURE 1.2

PROPORTION OF THE TOTAL CREDIT IN CHINA'S ECONOMY (2006 AND 2014)

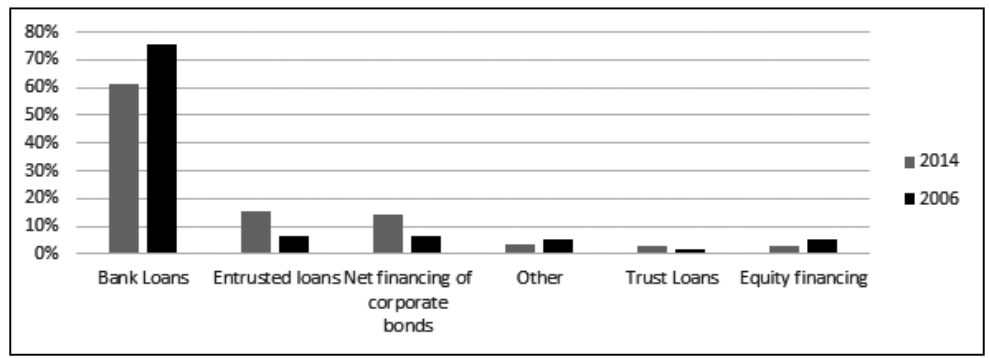

Source: People's Bank of China (PBOC)

Before 2004, SOBs were $100 \%$ controlled by China's government. However, since the restructuring of SOBs in 2004, with important IPOs, they turned into «Joint-stock corporations», but the effective control is still exercised by China's government. Central Huijin Investment (whose rights are exercised by the State Council) has the control of the major ownership of main SOB's, policy banks, small financial institutions and asset management corporations (AMCs) or «Big Four Bad Banks».

SOBs conceded a great deal of loans at low interest rates to SOEs and, simultaneously, they limited the availability of credit to private companies. However, that practice has been burdensome for SOBs, given the low profitability of SOEs. As a result, those loans turn into bad debts eventually.

${ }^{6}$ Estimation according to the Balance Sheet of the major five SOBs in Dec-2015 was $\$ 8,084 \mathrm{bn}$, and the Total Social Financing provided by China's National Bureau of Statistics that in 2016 was a $212 \%$ of China's GDP, equivalent to $\$ 24,138 \mathrm{bn}$. 
The SOBs are commonly known as «Big Five» and, despite the high amount of bad debt that they generate, they still have significant profits (due to favourable regulation to SOBs of banking interest rates by PBOC). The «Big Five» altogether represent a 33\% of Total Social Financing ${ }^{7}$ in China (see Table 1.1)

The regulation of interest rates creates a transfer of funds from households to major lenders of $4 \%$ of GDP as an annual average. This hidden subsidy incentivizes the loans of financial institutions to SOEs. This scheme fosters China's investment, which otherwise would have been lower.

Behind this over-dimensioned SOBs with significant profits, there is a hidden and uncomfortable truth: as the loans conceded to SOEs turn into bad credits, the Non-Performing Loans (NPL) ratio increases and the profitability declines. Therefore, China's government designed a method to shore up SOBs recurrently. China's government created four "bad banks" or Asset Management Corporations (AMCs). They buy the bad debts of SOBs, at the time PBOC along with Ministry of Finance inject money directly to AMCs.

The AMCs are five in total: China Orient, Huarong, Great Wall, China Cinda and Huida (the latter ascribed to absorb credits from PBOC). They had 10 years to recover the NPL transferred from the banks, but they are still in operation since the government set up the AMCs in 1999. Also, they have not been transparent in their operations. An estimation from the BIS ${ }^{8}$ points that the amount of NPL from major banks amounted to \$215bn only during 1999-2000. More recently, AMCs required another $\$ 5 \mathrm{bn}$ to continue operating $^{9}$, indicating their underlying financial problems.

7 The concept is a broad measure of the nation's yearly flow of liquidity. As a result, it is not comparable to figures reported by other countries either for credit origination or for overall financing.

${ }^{8}$ M. Guonan and S. Ben (2002).

${ }^{9}$ Trivedi (2016). 
TABLE 1.1

THE FINANCIAL FIGURES OF THE BIG FIVE OR STATE OWNED BANKS (SOBS)

\begin{tabular}{|c|c|c|c|}
\cline { 2 - 4 } \multicolumn{1}{c|}{} & \begin{tabular}{c} 
Net \\
Income* \\
\cline { 3 - 4 } \multicolumn{1}{c|}{}
\end{tabular} & $\begin{array}{c}\text { Balance Sheet } \\
\text { size } \\
\text { Bank of China }\end{array}$ & $\begin{array}{c}\text { Share of Total } \\
\text { social financing** } \\
7 \%\end{array}$ \\
\hline $\begin{array}{c}\text { Industrial and Commercial } \\
\text { Bank }\end{array}$ & 31 & 2261 & $9 \%$ \\
\hline $\begin{array}{c}\text { China Construction } \\
\text { Bank }\end{array}$ & 25 & 1801 & $7 \%$ \\
\hline Agricultural Bank of China & 19 & 1707 & $7 \%$ \\
\hline Bank of Communications & 8 & 680 & $3 \%$ \\
\hline Total & 100 & 8084 & $33 \%$ \\
\hline
\end{tabular}

${ }^{*}$ Data in billions of dollars **Percentage of the Total Social Financing Source: Yahoo finance, IFM, Bloomberg

FIGURE 1.3

BREAKDOWN OF BANK'S CREDIT BY TYPE OF INSTITUTION

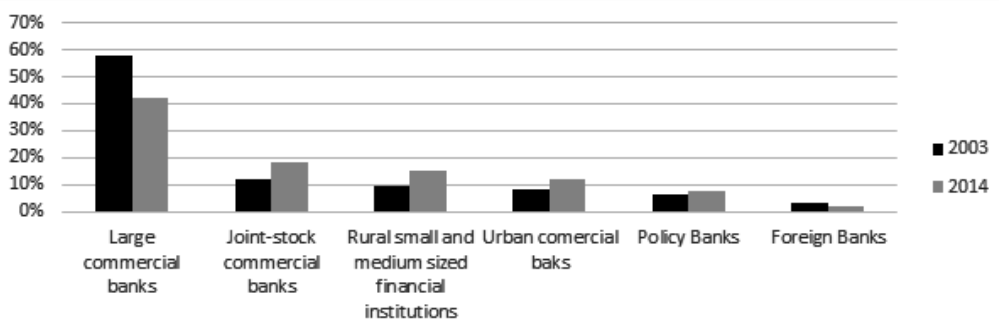

Source: China Banking Regulatory Commission (CBRC)

SOBs have been restructured from 1998 to current days, with a cost above of $35 \%$ of GDP, through a wide-range of methods. At the beginning (1998-2000), China's authorities lowered the Reserve Requirement Ratio (RRR), and with the liquidity generated, the banks bought government bonds. Then, the government injected capital (\$5bn) and transferred bad loans to AMCs (\$170bn). In the second 
period (2000-2008), the banks cancelled a part of bad credits with its own capital, and they received ( $\$ 57 \mathrm{bn}$ ) from the government in foreign reserves. Moreover, they transferred bad loans to AMCs (\$120bn). Also, the banks went to an IPO to acquire capital and issued bonds, including international investors. Recently (20082016), when SOBs face distress events and the interbank market indicate problems, the PBOC acts ordering liquid banks to give money to illiquid banks ${ }^{10}$, and finally injecting more liquidity into banking sector. Additionally, China's government approved in 2015 a debt-to-equity bonds swap (\$612bn) to recapitalize SOBs. In mid-2016, it endorsed an additional debt-to-equity swap (\$152bn) and an exchange of bad loans given to local governments for bonds (\$100bn).

As we can notice, the financial regulation is oriented to protect and guarantee the monopolistic position of SOBs in CFS. The primary rules include a limit to the loan volumes which can be issued (each part is apportioned to individual banks), a loan to deposit ratio of $75 \%$, a reserve requirement ratio of $19.5 \%$, and the already mentioned controlled lending and borrowing interest rates. Additionally, the top positions of SOBs are filled by the organization department of CPC, and these chosen executives often move to senior state positions over the course of their career.

Once we have analysed China's banking system, we will investigate China's stock markets. As we showed in Figure 1.2, equity and bond markets represent only a small proportion $(17 \%$ as of 2014) of the total credit of China's economy. Together, they represent $\$ 4,200 \mathrm{bn}$, (38\% of China's GDP) ${ }^{11}$. In comparison with developed countries, this is very low. In USA, only the market capitalization of the index S\&P500 in 2015 was 105\% of GDP.

Most China's companies tend to use other financing alternatives. For this reason, the market crash experimented in China in the summer of 2015 and early in 2016 is not as damaging for its economy as it would have been in USA.

${ }^{10}$ That was the case in June 2013 in the event known as Shibor crisis. More information: The Economist (2013).

${ }^{11}$ According to PBOC, Corporate bonds and Equity financing in 2014 were RMB $28,166 \mathrm{bn}(\$ 4,280 \mathrm{bn})$, while the Total Social Financing was $212 \%$ of GDP. 
These markets have many restrictions, with specific requirements to issue bonds or to be listed in the stock markets are very demanding. For this reason, China's companies often prefer to be listed in more flexible markets such as New York Stock Market and Hong Kong Stock Exchange. Moreover, Chinese investors have limitations on overseas investment due to capital controls, and foreign investors can invest only in Shenzhen and Shanghai through Hong Kong Stock Exchange, limited to some companies and some amounts.

A-shares are offered by China's SOEs, which trade in Shenzhen and Shanghai Stock Exchanges. Also, A-shares are typically quoted in RMB and traded by Mainland Chinese citizens. Foreign investments in these businesses are regulated through the Qualified Foreign Institutional Investor System. In contrast, China's SOEs offering H-shares are listed on Hong Kong Stock Exchange. Also, $\mathrm{H}$-shares are quoted in Hong Kong dollars and freely traded by all types of investors.

As we have seen, China's government policy creates a vast and concentrated banking sector, which reduces the credit available to private companies. This situation is unfortunate because private sector in China accounts for $60 \%$ of GDP while receiving only $20 \%$ of bank loans ${ }^{12}$. Consequently, given the burdensome financial regulation in China, there are incentives to the emergence of the well-known China Shadow Banking (CSB). Small and medium enterprises, which need funds to operate, are willing to pay substantial annual interest rates (often above $30 \%$ ) to microcredit companies. At the same time, the savers with low returns in their SOBs deposit accounts are encouraged to put their money in CSB.

The creation of CSB during the 2000s forced China's authorities to recognize that financial sector needs to be liberalized. Also, the government started in 2013 to limit the activities of CSB. The Financial Stability Board (FSB) defines CSB as «credit intermediation involving entities and activities outside the regular banking system ${ }^{13}$. The main activities, which are developed within the CSB are loans by trust companies, corporate entrusted loans, microfi-

12 See Sheng, Andrew, Chow and Edelmann (2013).

${ }^{13}$ Elliott, Douglas, Kroeber and Q. Yu Qiao (2015). 
nance companies, pawn shops and Wealth Management Products (WMPs).

WMPs are financial products offered in CSB to wealthy investors, promising a higher return than the deposits of SOBs, and payable in a short-term period. In practice, WMPs are a substitute of conventional deposits. Non-conventional financial institutions use funds to invest in long-term horizons in a wide-ranging portfolio of assets, which includes investment in real estate and local governments. As it can be noticed, this system uses maturity mismatching, which can be risky in case that the bank's liabilities cannot be rolled over (when a liquidity crisis triggers). Moody's investment estimated that WMPs make up 25\% of GDP or $\$ 2.25$ trillion ${ }^{14}$.

The operation of WMPs resembles the process of CDOs used by US banks before 2008 to keep the loans off-balance sheet. It is widely-believed that CSB is sowing the seeds of a next financial crisis because of its risky activities. They operate with smaller safety margins and with less transparency than the opposite side. Some authors argue that the CSB is not so worrisome, as the relative size is small ${ }^{15}$ and in the case of a distress event, the commercial banks and fiscal authorities have enough resources to tackle the potential crisis.

However, in accordance with Austrian School perspective, our vision of CSB is different from the standard CSB literature. The existence of CSB is positive for Chinese people, thereby increasing the share of market-driven financial sector in China's economy. It boosts competition in CFS, dragging down effective interest rates and financial costs. Furthermore, it allows people to avoid burdensome financial regulation. Moreover, the lack of government guarantees and lender of last resort facilities from central banks in CSB are positive incentives for these market participants to behave properly.

${ }^{14}$ W. Jiang (2015).

${ }^{15}$ Despite the rapid and recent growth of China's shadow banking ( 5 consecutive years with an annual growth above $30 \%$ ), still occupy a proportion below $65 \%$ of GDP, very far away from developed countries (World's shadow banking $120 \%$ of GDP, US shadow banking $150 \%$ of GDP). 
In fact, as we will analyse latter in Section 1.3, a crisis is a necessary restructuring process to eliminate discoordination failures created by state intervention. This restructuring process struggles to appear in China's economy due to the excessive control of CFS by China's authorities. Therefore, a crisis is more likely to occur in freer markets. For this reason, we believe that if CSB finally originates a financial crisis, it will be the beginning of the coordination process in the economy. Therefore, CSB, even though can potentially be a source of financial risk, it will be the instrument to reduce economic imbalances in the long term. But we should also stress that if free banking is not adopted in future, those recurrent crises will damage China's economy. Adopting free banking competition with no central bank can help China to avoid the economic discoordination.

\section{Foreseeable Effects on China's Economy according to Austrian Business Cycle Theory}

As we have observed throughout this chapter, the majority of the total credit available in China's economy is controlled by the state, through «Big Five» SOBs. At the same time, SOBs give most funds to unprofitable SOEs (they account for about $40 \%$ of industrial assets, with only a $4 \%$ of ROA - return on assets - vs $11 \%$ ROA of private enterprises). Given the low profitability of SOEs, most credit turns into bad loans years later. As a result, SOBs increase their NPLs ratios. Eventually, government would bail out SOBs by using four large bad banks or AMCs.

This scheme is a hindrance for private companies, as the credit availability shrinks, despite the high liquidity available in China. Private companies, which are the most dynamic part of China's economy, need funds to operate. As China's market economy thrives, demand for funds will grow. Under this circumstances of low credit offer and high credit demand, private companies are willing to pay higher interest rates for funds, which creates an incentive to savers to give credit to private companies. Those incentives were the origin of CSB.

Against this backdrop, the PBOC also manipulates interest rates, monetary supply and exchange rates (see Section 1.1), thereby 
inducing to an orchestrated credit expansion, which is not supported by the voluntary savings of Chinese people, but shored up by the government intervention.

According to $\mathrm{ABCT}$, when monetary supply and interest rates are not set freely by the market but manipulated, there will be a discoordination in financial system, which will generate a business cycle. If interest rates are not set according to the real savings level, entrepreneurs will have credit availability depending on intervention, but not according to real market signals. As a consequence, some investments, at first sight become profitable. In a market without governmental intervention, those projects would be not profitable. But as the effect of the decreasing artificial interest rate, they are «earning money». However, given that savings are not enough, there will be no enough consumption to make the investment profitable.

However, business cycle is a process that takes several years. Firstly, more artificial credit is available for entrepreneurs. Then, more investments are undertaken to create more products. In this stage, the price of capital goods increase. However, given that the level of savings does not increase, the price of consumer goods will increase as well. The workers hired in the new projects will consume. Thus, the investments undertaken in capital goods will increase both consumer and capital goods' price. This process is known as inflation.

In the next step, consumption industries will increase their profit margin, while the rest of the industries will see their profit margins decrease steadily until they become unprofitable. At this moment, entrepreneurs start to liquidate malinvestments. There will be bankruptcies and higher unemployment. Financial institutions perceive higher risk. They will increase interest rates and the availability of credit shrinks. Therefore, deflation may arise in economy in the time of the restructuring process.

Evidence points that China's authorities underpinned a huge credit expansion. According to official data, during the 1993-2015 period, China's GDP grew by a factor of 8 and inflation by 2.45 . However, base money multiplied 21 times and broad money 11 times (see Table 1.2). The authorities cannot control directly inflation, GDP and broad money, but they may decide the monetary base. 
TABLE 1.2

GROWTH OF MAIN MONETARY INDICATORS (1993-2015)

\begin{tabular}{|c|c|c|c|c|c|}
\cline { 2 - 6 } \multicolumn{1}{c|}{} & Broad money & Base money & CPI & PPI & GDP \\
\hline $1993-2015$ & $11 x$ & $21 x$ & $2 x$ & $2 x$ & $8 x$ \\
\hline
\end{tabular}

Source: IMF, Bloomberg

In China, the process explained by $\mathrm{ABCT}$ is happening and concentrating in monetary and financial sector, shipping industry and real estate sector. However, the restructuring process might be slower than usual in China. In less intervened economies, the restructuring process is relatively fast and efficient, but in China the government has stronger power to manage financial system, making the restructuring process slower and harder to operate.

In China, the liquidity provider (PBOC), the lender (SOBs) and the entrepreneurs (SOEs) are part from the government (see Section 1.2). According to Austrian School Economics, information and knowledge can only be transmitted through individuals and in fact is created by individuals. Thus, it is impossible for central planners to manage information and knowledge better than individuals do. It is not only that money supply and interest rates are manipulated, but also that the majority of the credit is managed by companies ruled by the State Council (China's Central Government).

Therefore, the credit allocation is made according to political criteria and in market criteria terms (even though they are still manipulated). Moreover, when a bankruptcy is necessary in the economy, China's government intervenes to bail out SOEs and SOBs, thereby hampering the restructuring process of economy and shoring up inefficient companies. It was not in vain that China's government approved an economic stimulus package plan, which accounted for 4 trillion RMB (\$0.6 trillion, RMB4 TSPP) to minimize the impact of global financial crisis on November $9^{\text {th }} 2008$. The program originated a surge in debt since 2009 among local government and SOEs. 
In conclusion, China has a significant discoordination between savers and investors, leading to a subsequent real economic discoordination. Nonetheless, the restructuring process of oversupply and malinvestment is not very efficient in China, with an enormous degree of intervention in CFS. Even more, capital controls in China reduce the investment alternatives of Chinese people.

With this theoretical framework, we can establish a relationship between the orchestrated credit expansion in China and the malinvestments created in China's economy (particularly in shipping industry and real estate sector), as we will analyse in the following sections.

\section{II SHIPPING INDUSTRY}

In this chapter, we will examine the influence on China's shipping industry (CSI) of the RMB 4 Trillion Stimulus Package Plan (RMB 4TSPP, equalling to $\$ 586 \mathrm{bn}$ ) during 2008-2016 period.

Why is it necessary to investigate CSI? First, maritime industry is critical for Chinese people. China is a huge country with significant trade connections with the world. Thus, transportation ships are vital for China. Secondly, CSI is a good example to illustrate $\mathrm{ABCT}$, as the sector has several productive stages clearly defined, which make the whole productive structure.

In the first section of this chapter, we will introduce CSI, including the definition of CSI and some important indicators used to monitor the situation of the sector. In the second section of this chapter, we will investigate in detail the impact of the RMB 4TSPP on CSI, by using ABCT.

\section{General Introduction of China's Shipping Industry}

\section{a) Definition of CSI and Industry Situation}

CSI comprises the enterprises that manage freightage in waterways and those that manufacture shipping supplies. CSI usually 
includes international transport in waterways, international freight forwarding agent, international shipping agency, ocean shipping tally, port logistics, shipbuilding, ship chartering, etc. ${ }^{16}$

Now most resources of Chinese shipping industry are controlled by SOEs, such as China Ocean Shipping (Group) Company (COSCO) and China Shipping (Group) Company (CSC). With the government support, this kind of enterprises make up most of the business in the industry: the ten most important shipping firms in China's stock market are all state-owned enterprises ${ }^{17}$.

\section{b) Industry Analytical Tools}

The most important indicators that are used to monitor the CSI situation are the following ${ }^{18}$ :

1.- China Coastal (Bulk) Freight Index (CBFI): CBFI is an index calculated by Shanghai Shipping Exchange, which describes the prices of transporting energy and food, including coal, metallic mineral, crude oil and grain. These products can be preserved for a very long time, therefore using ships for transporting them is cost-effective. This is the main way used to carry goods in China.

2.- The Baltic Dry Index (BDI): BDI is an index calculated by the famous British private maritime transportation consulting company Baltic Exchange, which describes the productivity condition of the global shipbuilding industry ${ }^{19}$. BDI is used to monitor the status of global shipbuilding market (including China).

\footnotetext{
16 See Gan and Qu (2010), pp. 49-50.

17 See Deloitte (2013), pp. 8.

18 According to Praxeology, statistical indexes are assistive tools in order to illustrate economic theories. Moreover, if indexes are designed by independent private sectors, they should be more accurate. More information about the use of statistical index, see Mises (1985) pp. 1-15. The indicators we describe in this section all match the conditions of being used in understanding the economic theory that we explained in this note.

${ }^{19} \mathrm{BDI}$ is published on its own website, see: http://www.drybulkindex.com.
} 
3.- The China Containerized Freight Index (CCFI): CCFI is an indicator calculated by Shanghai Shipping Exchange ${ }^{20}$, which describes the prices and the trend of transporting with Chinese export containers. CCFI includes China's export shipping services all around the world. As ships carry most export goods, CCIF explains the real export performance of Chinese economy. The index is widely adopted by maritime industry and market exchanges to analyse China's export performance.

\section{How the Stimulus Package Plan influences Chinese Shipping Industry}

We now discuss how the stimulus package plan influences CSI. We made a simple chart of a standard productive structure (Figure 2.1) -described also in ABCT- to illustrate how the bank credit evolved and how it affected CSI. In fact, the productive structure of CSI is rather complex, but for the sake of simplicity we will only use a few stages.

FIGURE 2.1

THE SIMPLE CHART OF THE PRODUCTIVE STRUCTURE RELATED WITH CSI

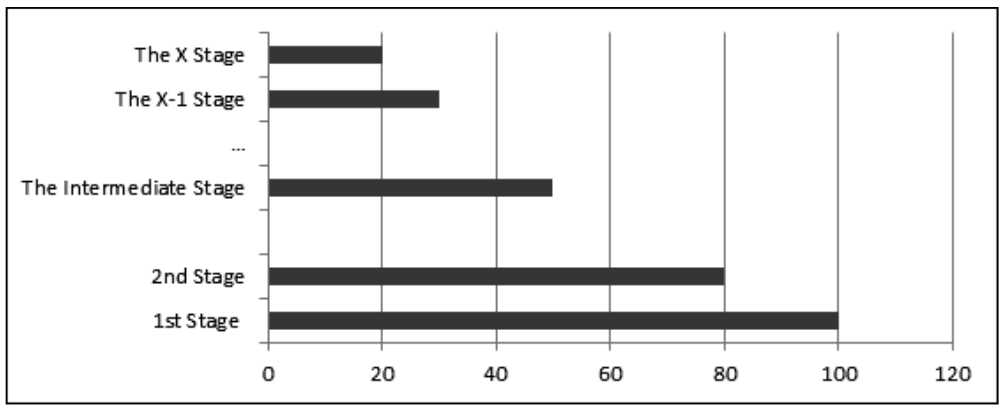

${ }^{20}$ Shanghai Shipping Exchange firstly published CCFI on April 1998. 
Figure 2.1 illustrates only five stages. The X-Stage ${ }^{21}$ represents the material development and outsourcing (such as coal, metallic mineral, crude oil and the cultivation grain). The transportation of raw materials (TRM) is in X-1 Stage, in which CBFI may well indicate the shipping traffic sustainability in CSI. At the intermediate stage, the shipping companies attempt to build more new ships after they receive bank loans. BDI is used to describe the situation in the shipbuilding industry. In the $2^{\text {nd }}$ Stage, containerships will be used to transport the goods, which will be consumed in $1^{\text {st }}$ Stage.

\section{a) The Impact of the Bank Credit on the Transportation of Raw Materials}

Figure 2.2 describes the tendency of the yearly growth rate of $\mathrm{M} 2$, fixed-asset investment (FAI), one-year deposit rate (ODR) and CBFI in China during 2008-2016 period. This figure clearly shows that after the credit expansion registered in 2008, the yearly FAI growth rate was in line with the yearly growth rate of M2. The yearly growth rate of M2 increased to 20.5\% in February 2009 from $17.8 \%$ in December 2008, after the State Council meeting in November 2008, which decided to issue more credit.

In order to expand credit, PBOC reduced ODR: it declined to $2.25 \%$ in December 2008 from $4.18 \%$ in August 2008. Consequently, CBFI quickly increased to 1675.55 in November of 2009 from 1113.51 in October of 2009. Nonetheless, the growth in CBFI was perceived at a later time than when the growth M2 and FAI was noticed. This is explained by a number of reasons. First, the money from bank credit will reach to the energy sector at the beginning. Once the energy production rises, the CBFI will grow. Second, energy is usually transported after a few months of storage in a warehouse. Third, it will be necessary to increase shipbuilding activity before raw material transportation increase, as it is the Intermediate Stage (Figure 2.1) in this sector.

${ }^{21}$ According to $\mathrm{ABCT}$, when bank credit creates an economic bubble, the last productive stage may disappear or become shorter. In the case of CSI, the productive stages do not disappear but shrinks. 
Nevertheless, this was an artificial expansion, not backed by voluntary savings. For this reason, it will lead to a decline in the future. However, to control inflation and overcapacity in energy industry, the China's central government decided to reduce the amount of money in circulation.

Reviewing Figure 2.2 again, in the period analysed (2008-2016), the highest circulation of RMB (M2 growth) was in June 2009, although declined afterwards. In line with this decline, even though ODR remained steady, the yearly FAI growth dropped to $26.60 \%$ in the February 2010. As before-mentioned, it exists a time-lag (approximately one year) among CBFI, M2, FAI, and ODR rate. Thus, CBFI dropped to 1299.56 in January 2011 from 1875.11 in October 2010 (a 30.7\% decline). Figure 2.2 shows the decreasing CBFI, which fell to 1055.15 in December 2013. In comparison with its highest point in January of 2008, it decreased by $58.8 \%$. The turnover of water transportation was 8 trillion tonnes in 2012, which was the lowest growth rate since $2008^{22}$.

According to $\mathrm{ABCT}$ and $\mathrm{CBFI}$, we find that the reason that explain the decline in the yearly growth rate of this industry is the credit bubble originated at the beginning, which busted when the increase of the lending rate had already affected the late stages of the productive structure. Once enterprises in the latter productive stages realized that their business was unprofitable, the business operations will stop, the energy consumption will drop, with the subsequent decline in energy prices. Later, the entrepreneurs would end their operations in the first stage of productive structure, then the transportation of raw material by ships would decline too.

If shipping industry transportation was declining, then the demand to build new ships will also decline, leading to a vicious cycle and a number of companies will face bankruptcy.

\section{b) The Influence of the Bank Credit in the Shipbuilding Industry}

According to the study of Deloitte Consulting ${ }^{23}$, in the Chinese dry bulk shipping market, the total shipments in 2012 were 98,000

\footnotetext{
${ }^{22}$ See Deloitte (2012), pp. 7-8.

${ }^{23}$ See Deloitte (2013), pp. 7.
} 
tonnes, but the quantity of scrap ships was 34,000 tonnes, whose rate of operating ships is $5 \%$. This suggest an excess capacity in shipbuilding industry. As one insider of COSCO said: "Most the loss is the investment in shipbuilding". The reasons that explain the existence of excess capacity are as follows.

FIGURE 2.2

THE YEAR-ON-YEAR GROWTH RATE OF M2, FIXED-ASSET INVESTMENT, ONE-YEAR DEPOSIT RATE AND BDI ${ }^{24}$ DURING 2008 TO 2016

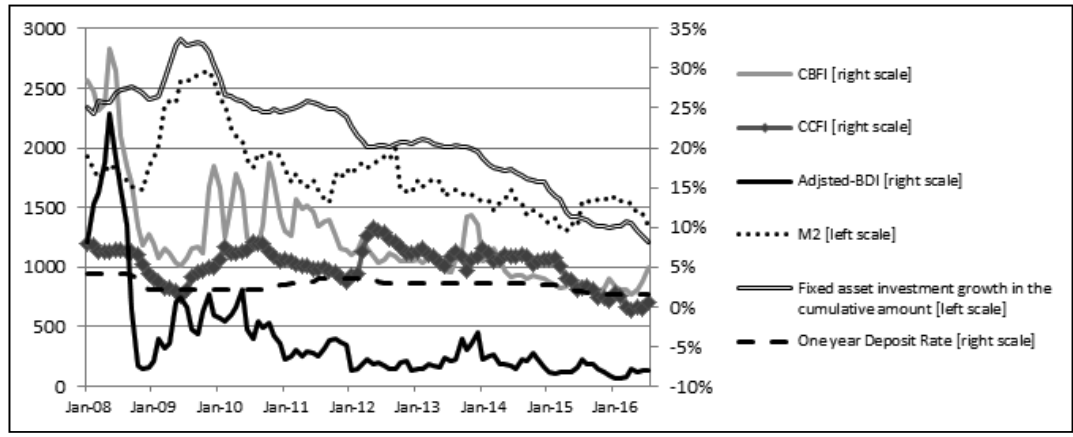

Source: BDI

First, the artificial bank credit expansion in energy exploitation gives a wrong signal for entrepreneurs in shipbuilding industry, as the entrepreneurs may conclude that there is strong need for raw materials transportation. They would decide to build more ships. Many prosperous Chinese shipping enterprises, such as COSCO and CSC, injected massive amounts in shipbuilding following the

${ }^{24}$ There is an indicator named China Newbuilding Price Index (CNPI) which is used to describe the numbers of the new built ships in China every month, as the data is not accessible, we use BDI, which is also used to described the shipbuilding industry in China because it also covers the shipbuilding industry of china, to be instead of CNPI. Usually China's shipping are tightly connected the global shipping industry because the majority of the new ships are built for international trade, which means that logically BDI could express the situation of the China's shipbuilding industry. 
government stimulus plan. The industries related to shipbuilding, such as ship machinery manufacturing, were also targeted by the stimulus plan.

Second, most shipbuilding enterprises in China are SOEs and they can get a bank credit easily, as most of the banking sector is also owned by the government. For this reason, these companies would receive with more probability part of the RMB4TSPP. As the shipping industry is vital for China's government, the entrepreneurs in the SOEs have bargaining power to negotiate with government officials a higher quantity of loans.

Third, recently the industry suffered a contraction. According to $\mathrm{ABCT}$, the bank credit expansion unbacked by voluntary savings could start again for a new turn ${ }^{25}$. According to many entrepreneurs in the shipping industry and government officials, the government stimulus plan was essential to maintain the economic growth, and in the case of an economic depression, the stimulus plan could «save» a great deal of enterprises and the economy. At the beginning of the credit expansion, when the production of ships increased significantly, the prices of the ships also increase. For this reason, shipping enterprises will hire more workers given that the relative wages are lower than before. But, once the restructuring process in the shipbuilding has begun, wages in shipping enterprises will increase faster than company costs, thereby increasing the relative wages. This effect is the so-called Ricardian effect, as described in ABCT.

\section{c) The Influence of the Bank Credit in the Transportation for Consumer Goods}

Figure 2.2 shows the yearly growth rate of M2, FAI, OYD rate and CCFI during 2008-2016. Like CBFI, CCFI has a similar trend with M2, FAI, and OYD rate since the middle of 2009. The yearly growth rate of M2 started to increase from January 2009 quickly. In June 2009, CCFI dropped to 763.31, which was the lowest point since January 2008 (a reduction of 35.6\%). CCFI increased to 1209.06 in

\footnotetext{
${ }^{25}$ See Huerta de Soto (2012), pp. 507.
} 
July 2010. After that, it decreased by $26.2 \%$ to 892.79 in December 2012. CCFI reached its peak at the end of May 2012, which was 1331.4. The lowest date of CCFI since 2008 was 632.36 in April 2016, which dropped 52.5\% comparing its peak in May 2012.

We found that the CCFI growth was unsustainable. According to Deloitte Consulting ${ }^{26}$, most of the shipping enterprises related to the transportation of consumer goods were suffering losses. In total, 13 shipping companies are listed in the stock market and all of them are SOEs. In 2012, 5 shipping companies amounted to RMB 102.6 bn ( $\$ 16.6 \mathrm{bn})$ of losses. 6 companies showed a declining income. COSCO, one of the biggest SOSEs, had a loss of RMB 8.10bn (\$1.3bn).

Moreover, other reasons may also support the SOSEs losses, such as the corruption posed by the central planning system embed in these companies or the lack of entrepreneurship. Be that as it may, if were not for artificial bank credit expansion orchestrated by the central bank, the loss would not had been so huge. Furthermore, overexploitation at $X$ stage (Figure 2.1) boosted shipbuilding activity at X-1 stage. Then, in the $2^{\text {nd }}$ stage, because of artificial bank credit expansion throughout intermediate stage and the $2^{\text {nd }}$ stage, more capital goods and consumer goods are created. As a result, transportation industry and enterprises dedicated to consumer goods will register a significant increase in their profits. However, as this process is not backed by voluntary savings, customers will not be demanding the fresh new products. In consequence, these businesses may well be found unprofitable afterwards, thereby forcing a great deal of enterprises in the industry to shut down.

\section{The newest bankruptcy in China's shipping industry}

In this part, we will illustrate the bankruptcy situation in CSI from 2015 until June 2016. In January 2016, more than 60\% of the enterprises of CSI showed a negative net income. Moreover, we will also analyse the situation of private-owned shipping enterprises.

\footnotetext{
26 See Deloitte (2013), pp. 7-8.
} 
Firstly, we will discuss the bankruptcy of SOSEs, while in the second part we will study the situation of private shipping enterprises.

\section{a) Bankruptcy of SOSES}

In China, even though SOSEs faces significant losses during financial crisis, they are still in operation, underpinned by government subsidies. Furthermore, the two biggest SOESs, (COSCO and CSC) monopolize China's main shipping lines, which are linked with important industrial cities like Shanghai, Guangzhou, Dalian, Wuhan and Chongqing. In these cities is where the industry intermediate stages are located. Even so, these companies still face losses.

Despite this monopolistic situation of SOSEs, they fail to generate profits, as they are unable to be competitive. Although COSCO monopolized most of the leading shipping lines in China, its $\mathrm{cu}^{-}$ mulatively loss was more than RMB 34.1bn until $2015^{27}$. In the case of CSC, the cumulative loss amounted to RMB 280 million $^{28}$ until 2015.

Considering these results, China's government decided to merge both COSCO and CSC at the end of 2015 to increase profitability. However, according to the socialism impossibility theorem, both companies will unlikely be able to increase competitiveness and profits. Six months after the merge, the new COSCO Shipping Corporation lost RMB 7.2bn. Meanwhile, China COSCO Shipping Corporation has laid off more than 300 thousand people ${ }^{29}$ employees.

\section{b) Bankruptcy of private shipping enterprises}

Private shipping enterprises did not receive any subsidy in the last two years. As we mentioned, at the start of 2016 more than $60 \%$ of

\footnotetext{
27 See Eworldship.com (2015).

28 See L. Sun (2016).

${ }^{29}$ See Y. Zhang (2016) and J. Yang (2015)
} 
the CSI enterprises lost money, whereas $40 \%$ of them faced liquidity squeeze, most of which are the private shipping companies ${ }^{30}$.

This is explained by the fact that China's financial system prioritize SOEs and availability of funds is limited for private enterprises. In February 2016, three private shipping companies faced bankruptcy. In a case, the company leadership disappeared, leaving significant losses and RMB $0.2 \mathrm{bn}$ of debt. In a different case, a private shipping company owed more than RMB 1 bn of the salary of its employees ${ }^{31}$.

III

REAL ESTATE

Now we will deepen in China's Real Estate Industry (CREI) from 2005 to the middle of 2016, which has been the primary focus of China's analysts because it has been crucial for China's economic growth. However, now it is in the spotlight due to the signs of financial risks, amid the commonly known ghost cities all around China, showing malinvestments and oversupply at the same time. In this chapter, we use ABCT coupled with empirical evidence to address important questions about CREI after the issuance of RMB4TSPP. This chapter is structured in four sections.

In the first section, we introduce an overview of CREI amid RMB4TSPP in 2008 and the description of the four cycles in CREI.

In the second section, we combine ABCT with empirical evidence to address important questions on CREI cycles. By doing so, we will analyse the degree of stability of credit expansion process in CREI, and the following real estate projects. It will be necessary to investigate relationships between loans, housing projects, housing prices, interest rates and salaries.

In the third section, we analyse the most important Real Estate Enterprises (REEs) to validate the financial status of the sector and geographical analysis of CREI, given the significant differences between cities when it comes to real estate. After illustrating the stag-

\footnotetext{
${ }^{30}$ See Pei (2016).

${ }^{31}$ See W. Wang (2015) and Cnhangyun.com (2015).
} 
es of each business cycle in CREI, we demonstrate that the general picture of the business cycles happens in CREI.

CREI register an artificial credit expansion and a credit bubble is created. On the other hand, production in other industries declines as scarce economic resources are dedicated in a relative higher proportion in CREI. Meanwhile, as the wage growth is lower than the growth of real estate prices, it becomes more difficult for people to pay back the credit. Our evidence suggests that CREI suffered several business cycles and that the duration of each business cycle become shorter and shorter, pointing that the probability of a bubble burst has increased over time.

\section{Overview and Risks of China's Real Estate Industry after 2008}

\section{a) Overview of the Real Estate Cycle}

In this part, we illustrate the general picture of CREI after 2008 until the mid-2016. We will outline the main functioning of the following parts: general credit expansion in China's economy and in CREI; the development of new real estate projects, underpinned by credit expansion; creation and extension of housing production; evolution of output and consumer prices; soaring private interest rates because of risks associated to malinvestments; companies in financial distress and overheating sectors; a comparison between the growth of real estate's prices and wages.

As housing becomes less affordable, some CREI programs turn into malinvestment: the demand is not enough to sell them and only it is possible to sell the project at a much lower price. We will use evidence to analyse the bankruptcy of real estate, related with financial sectors and ghost cities in the later part of this chapter.

In order to prevent a bubble burst, PBOC injected more credit to extend the ongoing bubble. At that time, a business cycle in CREI finishes and a new cycle starts and real estate prices begin to rise again.

Before we analyse CREI before 2008, we will outline the general situation in the industry. After the issuance of RMB4TSPP in No- 
vember 2008, the yearly growth rate of housing prices, the yearly growth rate of credit to real estate consumers and the yearly growth rate of credit to real estate developers reached its peak (Figure 3.1). Meanwhile, comparing the evolution of housing prices with the evolution of wages, the gap between both indicators increased over time, reaching its peak in 2014 (Figure 3.2).

If the divergence between housing prices and wages increases, housing becomes less affordable, unless they receive a mortgage loan. At the outset, real estate prices will raise above salaries and therefore housing affordability will decrease, which means that they will have more difficulties to pay back the mortgage loan (at some point the NPL ratio will rise). Simultaneously, investment in real estate is still profitable because interest rates are low, given the recent artificial credit expansion.

Moreover, the more investment in real estate, the less investment in other productive stages, and less workers will be available for other productive activities. Therefore, higher demand for workers and resources to undertake real estate project will push up costs and inflation. Housing affordability will decline over time, while company costs will increase over time. At some point, the financial situation of real estate companies will weaken and commercial banks will raise interest rates, on the back of higher perceived risk. At that time, the credit bubble is about to burst. 
FIGURE 3.1

THE FOUR CYCLES IN CREI (2005-2016) $)^{32}$

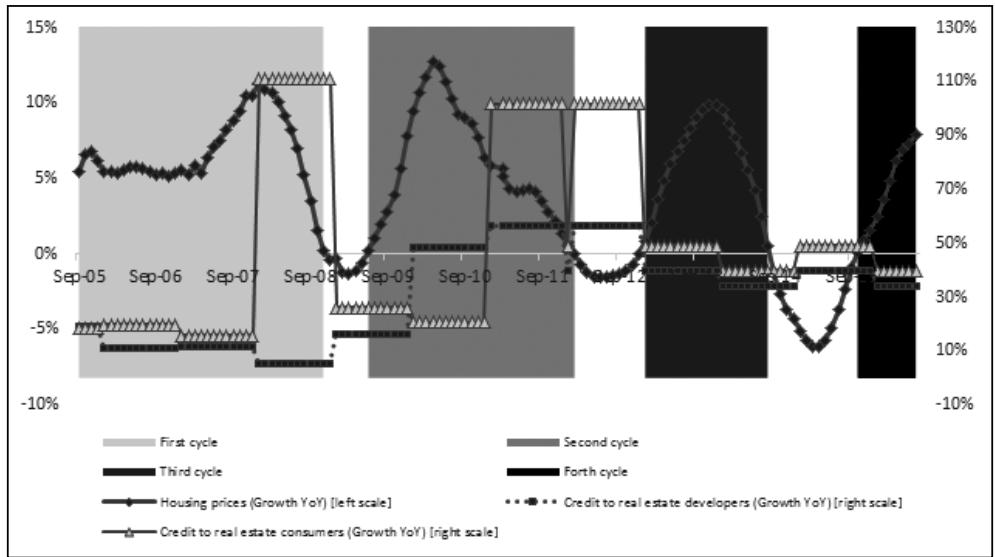

Source: National Bureau and PBOC (2016.6)

FIGURE 3.2

INFLATION IN CREI

AND THE GROWTH OF WAGES (2007-2016)

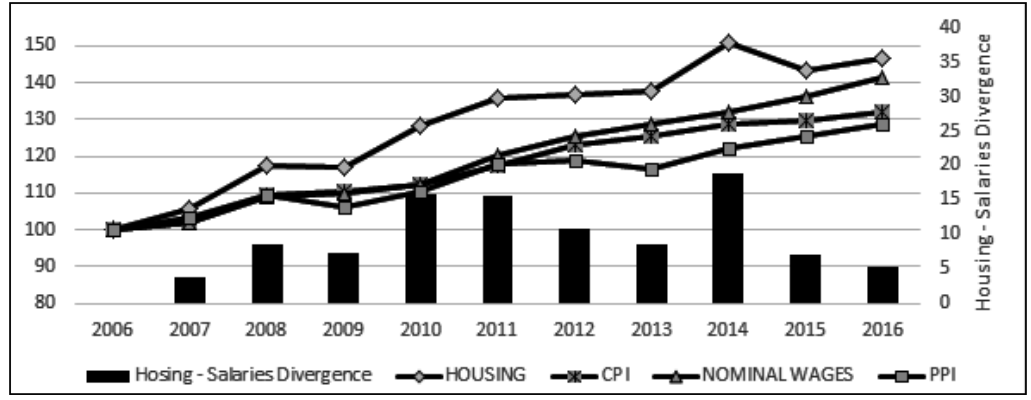

Source: NBEC (2016.6),

${ }^{32}$ In Figure 3.1, we include new added real estate development loans both for developers and for consumers to clarify our argument. Both the credit to consumers and developers would increase housing prices, but in a different way. Credit to consumers would increase the housing demand, thereby increasing housing prices. Meanwhile, if developers receive more credit from commercial banks, the demand for building materials would increase, with the subsequent increase in the construction materials prices. Therefore, the real estate project will be more expensive. But this second effect is not immediate in housing prices but has a time-lag between the higher cost for the developers and higher housing prices for consumers. 
According to Figure 3.1 and Figure 3.2, that is the situation in CREI. The effect of the stimulus effect of the RMB4TSPP on CREI seems to have lasted until February 2012. Meanwhile, PBOC issued a new credit tranche giving more room to commercial banks to decrease interest rates and further increase loans. This cyclical process was perceived at least four times, according to empirical evidence. In Table 3.1 we illustrate the four sub-economic cycle in CREI.

TABLE 3.1

DURATION OF THE RISE AND FALL IN HOUSING PRICES BY PERIOD (NATIONAL AVERAGE)

\begin{tabular}{|c|c|c|c|c|}
\cline { 2 - 5 } \multicolumn{1}{c|}{} & $\begin{array}{c}\text { First cycle } \\
\text { (Sep 2005 } \\
\text { Jan 2009) }\end{array}$ & $\begin{array}{c}\text { Second cycle } \\
\text { (Jan 2009 } \\
\text { Feb 2012) }\end{array}$ & $\begin{array}{c}\text { Third cycle } \\
\text { (Feb 2012 } \\
\text { Sep 2014) }\end{array}$ & $\begin{array}{c}\text { Fourth cycle } \\
\text { (Sep 2014 } \\
\text { Current) }\end{array}$ \\
\hline $\begin{array}{c}\text { Rise } \\
\text { in housing } \\
\text { prices }\end{array}$ & 42 months & 33 months & 21 months & $\begin{array}{c}\text { so far 15 } \\
\text { months }\end{array}$ \\
\hline $\begin{array}{c}\text { Fall } \\
\text { in housing } \\
\text { prices }\end{array}$ & 4 months & 9 months & 13 months & $i ?$ \\
\hline
\end{tabular}

Source: NBS

Empirically and theoretically, each cycle has its own starting point, peak and ending point. We can found that the duration of each cycle has shortened, which means that the marginal utility of credit declined over time. In other words, a significantly larger proportion of credit will be needed in next cycle to have similar effects than in previous cycles. At each starting point of each cycle, a credit expansion was registered, leading the real estate prices to increase afterwards.

Meanwhile, when investment in real estate increase and market dynamics weaken financial position of real estate companies, commercial banks will raise interest rates to prevent a spike in NPL ratio. As we mention before, housing affordability will decrease (lower revenues for real estate companies) and company costs will 
rise (higher expenses for real estate companies). Inevitably, a proportion of real estate projects will turn into malinvestments and bankruptcy rate will increase.

However, bankruptcy and ghost cities may cause market panic and trigger political uncertainty. In this sense, China's authorities will attempt to shore up the artificial credit expansion. According to Figure 3.2, new credit increases the proportion of the prevailing bubble while the marginal utility of the credit declines, which means that in each cycle credit expansion will be more difficult to shore up. In the next section, we will analyse in detail the four cycle in CREI after 2008. We will provide specific details of the general picture of REEs and cities who are involved in CREI.

FIGURE 3.3

INVESTMENT IN REAL ESTATE (LEFT) AND PRICES EVOLUTION IN TIER I CITIES (RIGHT)
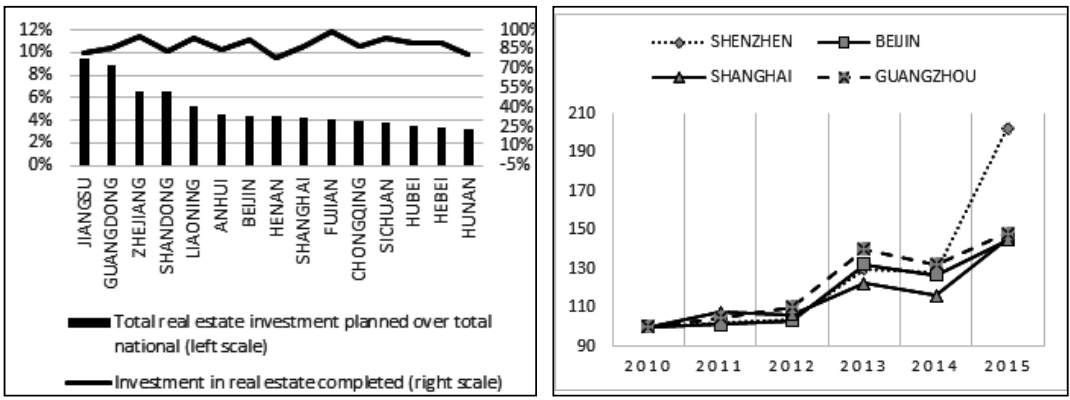

Source: NBS

b) General Picture of China's Real Estate Enterprises and Cities

The data provided by NBSC is an indicator to have an overall picture of CREI. However, a comprehensive investigation will require a more detailed analysis to understand the different segments of CREI. Therefore, firstly in this section, we will develop a city-level analysis and secondly we will make a review of REEs.

As we will see throughout this section, the CREI can be split up at least into four parts, according to the different behaviour of 
those sections. These four parts are different categories of cities by importance.

Tier I cities are the most important, as they are the most developed part of China and recently they receive most real estate investment flows. In recent years, in terms of real estate prices, Tier I cities performed the best, while Tier II performed weaker and Tier III/IV have fallen continuously, showing that there is a market segmentation in CREI. Nonetheless, during 2005 to 2009 there was growth rates of housing prices above $300 \%$ in small and medium cities.

According to the housing affordable indicator of The Economist, Tier I cities are twofold less affordable than the national average and this gap is increasing over time. In recent years, while the housing prices of Tier I cities soared (see Figure 3.3), the prices of the rest of cities remained stable or even fall.

There are plenty of reasons for such a surge. It is more evident that the steady loose monetary policy of PBOC (see Chapter 2) pumps up money in the system, along with China's top five banks that gave credits to the sector of $\$ 1.9$ trillion at end of 2015, representing $28 \%$ of total loans. Moreover, the capital controls in China hamper the investments in foreign countries. Even more, the financial turmoil created in China's stock markets after the slump in share prices in the summer of 2015, provoking that a great deal of Chinese investors will seek for alternative investments, among them is real estate in Tier I cities.

Remarkably, the housing prices of Shenzhen multiplied by two in only five years. The promising technology industry in Shenzhen, the limited supply and less restrictive conditions to buy houses, give some fundamentals to Chinese investors. According to Centaline, nearly $30 \%$ of Shenzhen citizens bought properties for investment purposes. Shenzhen and Shanghai are among the most modern cities in China, with good transport conditions, smooth labour markets and a relative good environment.

Be that as it may, China is enormous and Tier I cities only represent $10 \%$ of total floor space sold. The majority of the real estate market is made up by Tier II cities. The costal Jiangsu Province account for nearly $10 \%$ of the total real estate investment planned in China, completed in 85\% (see Figure 3.3), followed by Guang- 
dong Province, one of the most developed region of China. Beijing and Shanghai are in in the seventh and ninth position respectively.

In addition, the oversupply is higher in smaller cities with higher floor space per capita, thereby giving disincentives to real estate investment in comparison with bigger cities.

The total amount of investment planned in China in 2014 was $\$ 7.6$ trillion or $73 \%$ of GDP, whose $14 \%$ is still to be completed. The plenty of liquidity created by PBOC, the captive investment in China due to capital controls, the glut concerns that smaller cities creates and the hopeless investment alternatives such as the stock markets, provoking that the majority of investors chose Tier I cities are the best investment, thereby worsening the China's bubble.

Our analysis would be incomplete without including an investigation of the companies' situation, that is essential to gauge the stability of the current system.

FIGURE 3.4

EVOLUTION OF CHINA'S

REAL ESTATE ENTERPRISES (2005-2014)

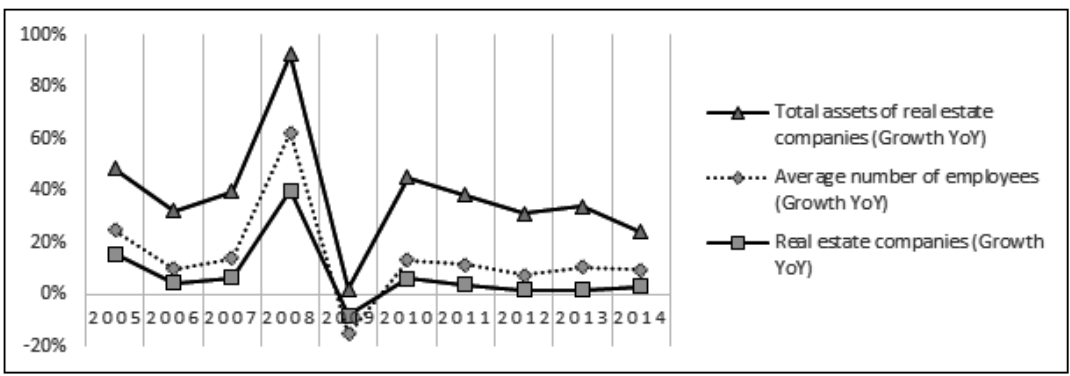

Source: NBS

In China, there are 94,197 REEs registered (2014). The majority of REEs are private (according to NBEC only 1.6\% in 2014 were SOEs).

The growth in the number of companies in the average number of employees and in the total assets of companies has been in line with the same trend. In 2008 the growth rate spiked in CREI due to 
the issuance of a large amount of credit by the China's regulators. In 2009, a new nationwide real estate sales tax was introduced into China to curb speculative investing. After that, the growth in REEs has been steady, as it is shown in Figure 3.4.

In our analysis of REEs, we have chosen a sample of the eight most important REEs in China, and all of them listed in Hong Kong Stock Exchange. China Resources, Sino Ocean and Poly are SOEs, whereas Greentown, China Vanke, Aguile, KWG and Shimao are private.

TABLE 3.2

CURRENT SITUATION OF THE MOST IMPORTANT REES

\begin{tabular}{|c|c|c|c|c|c|c|c|c|c|}
\hline $\begin{array}{c}\text { Unit: } \\
\text { Millions } \\
\text { dollars }\end{array}$ & $\begin{array}{c}\text { China } \\
\text { Resources }\end{array}$ & Greentown & $\begin{array}{c}\text { China } \\
\text { Vanke }\end{array}$ & Agile & KWG & $\begin{array}{c}\text { Sino } \\
\text { Ocean }\end{array}$ & Shimao & Poly & Total \\
\hline EBITDA & 5,002 & 321 & 5,776 & 1,222 & 439 & 794 & 2,480 & -226 & 15,807 \\
\hline $\begin{array}{c}\text { Debt } \\
\text { over } \\
\text { assets (\%) }\end{array}$ & $20 \%$ & $31 \%$ & $13 \%$ & $32 \%$ & $35 \%$ & $35 \%$ & $29 \%$ & $41 \%$ & $30 \%$ \\
\hline $\begin{array}{c}\text { Free } \\
\text { Cash } \\
\text { Flow (FCF) }\end{array}$ & 4,521 & -37 & 2,425 & 1,032 & 9 & 880 & -382 & 0 & 8,447 \\
\hline $\begin{array}{c}\text { Cummulative } \\
\text { FCF } \\
(2004-2015)\end{array}$ & -464 & $-4,638$ & 7,545 & $-3,883$ & -615 & $-5,350$ & $-7,986$ & $-5,164$ & $-20,555$ \\
\hline
\end{tabular}

Source: Bloomberg and Hong Kong Stock Exchange

According to the evidence, 7 of the 8 companies reported a positive EBITDA, amounting up to $\$ 15.8 \mathrm{bn}$ in 2015 . The indebtedness is not burdensome, as the total debt over total assets is in average $30 \%$. However, the capacity of the companies to make cash (Free Cash Flow, FCF) is disappointing. Only half of the companies are able to make significant FCF. Even more, the cumulative FCF (the cash made by the companies since 2004) has been substantially negative (\$-20.5bn). In general, the situation of REEs is not worrying but are vulnerable. In case they have to face a sharper disruption in the market than the experimented one in 2012, a surge in mergers and acquisitions in the sector (and potentially some bankruptcies) is probable. 
TABLE 3.4

VARIATION IN MAIN INDICATORS SINCE 2004

IN THE MOST IMPORTANT REES

\begin{tabular}{|c|c|c|}
\cline { 2 - 3 } \multicolumn{1}{c|}{} & EBITDA & Debt \\
\hline China Resources & $86641 \%$ & $-45 \mathrm{pp}$ \\
\hline Greentown & $187 \%$ & $-11 \mathrm{pp}$ \\
\hline China Vanke & $2715 \%$ & $-50 \mathrm{pp}$ \\
\hline Agile & $1999 \%$ & $39 \mathrm{pp}$ \\
\hline KWG & $2314 \%$ & $-13 \mathrm{pp}$ \\
\hline Sino Ocean & $1700 \%$ & $-3 \mathrm{pp}$ \\
\hline Shimao & $12608 \%$ & $56 \mathrm{pp}$ \\
\hline Poly & $-1371 \%$ & $212 \mathrm{pp}$ \\
\hline Average & $13349 \%$ & $23 \mathrm{pp}$ \\
\hline
\end{tabular}

Source: Bloomberg and Hong Kong Stock exchange

To assess the performance of REEs along with its history, we will explore the evolution of EBITDA and debt since 2004 to now. According to this figures, the companies (with the exception of the SOE Poly) performed quite well. In average, EBITDA was multiplied by 133, although the debt was also increased in 23 points. The best performer was China Resources multiplied by 866 EBIDTA and a reduction in 45 points in debt. The soaring housing prices over this period (2004-2015) in China weighed on this performance.

TABLE 3.5

VARIATION IN MAIN INDICATORS SINCE 2012 IN THE MOST IMPORTANT REES

\begin{tabular}{|c|c|c|}
\cline { 2 - 3 } \multicolumn{1}{c|}{} & EBITDA & Debt \\
\hline China Resources & $82 \%$ & $-20 \mathrm{pp}$ \\
\hline Greentown & $-77 \%$ & $57 \mathrm{pp}$ \\
\hline China Vanke & $46 \%$ & $-41 \mathrm{pp}$ \\
\hline Agile & $-24 \%$ & $-2 \mathrm{pp}$ \\
\hline KWG & $-16 \%$ & $-6 \mathrm{pp}$ \\
\hline Sino Ocean & $-14 \%$ & $39 \mathrm{pp}$ \\
\hline Shimao & $55 \%$ & $-8 \mathrm{pp}$ \\
\hline Poly & $-131 \%$ & $9 \mathrm{pp}$ \\
\hline Average & $-10 \%$ & $5 \mathrm{pp}$ \\
\hline
\end{tabular}

Source: Bloomberg and Hong Kong Stock exchange 
However, now we will analyse a quite different period (20122015), in which there were 24 months with decreasing housing prices (see Section 3.2). According to the variation since 2012, only 3 out of 8 companies were able to increase EBITDA. In average, EBITDA declined by $10 \%$, whereas the debt ratio increased by 5 points. The most affected companies were Greentown, Agile, KWG, Sino Ocean and Poly.

\section{The Sub Crisis Period beyond China's Real Estate Industry}

In the first place, as we may observe in Figure 3.1 and Figure 3.2, the housing prices in China show a cyclical behaviour, with periods of rising price followed by periods of decreasing price. However, as we may notice the years of growing were longer at the beginning but shorter over time. In that sense, the first rise time of the indicator had a duration of 41 consecutive months from September 2005 to January 2009. The second cycle had a rising period of 38 consecutive months (from January 2009 to February 2012). The third cycle had a growing period of 36 consecutive months (from February 2012 to January 2015). The fourth cycle has a period of 18 consecutive months (from January 2015 to the middle of 2016).

We define a ghost city as a city with a population density lower than 3,900/ sq. km. and which is full of new built real estate whose living rate is lower than $40 \%$ after the house has been built more than 5 years $^{33}$.

\section{a) From September 2005 to January 2009 (3 years and 5 months)}

Now we will focus in the different sub-periods of the economic cycle mentioned in section 3.1. Firstly, we will review the first cycle from September 2005 to January 2009.

When PBOC lowered interest rates, the yearly growth rate of housing prices (YoYHP) started to accelerate since September 2005, when the yearly growth rate was only $7 \%$ and reaching its peak

33 See Sina.com (2013). 
with a $11 \%$ growth in in August 2008. Given the increase of interest rates and a weaker situation of the CREI, the yearly growth of investment in CREI declined to $-1 \%$ in May 2009 from its peak in August 2008. At the time when China's government approved the RMB4TSPP in November 2008, the YoYHP was nearly zero, being the worst growth rate since September 2005.

As showed in Figure 3.1 and Figure 3.2, we found that the yearly growth rate of credit to real estate consumers (YoYCCs) were $110 \%$, which was much higher than in 2007 (16\%). RMB4TSPP was the main driver behind the dramatic growth of the credit, approved in November 2008. At that time, several cities in China saw its real estate vacancy rates to increase, so that led China's government to foster credit expansion to consumers, to reduce the excess capacity in CREI. Meanwhile, the yearly growth rate of credit to real estate developers (YoYCDs) was only 5\% in 2008.

In this period, wages followed a similar trend than housing prices, so that housing was relatively affordable. However, once central bank used monetary stimulus to bolster real estate industry, the gap between wages growth and the housing prices growth increased over time, according to the evidence showed in $3.2 \mathrm{sec}-$ tion.

Although there were neither significant bubble nor ghost cities in China at that time, there were some warning sings. According to a study in the middle of $2008^{34}$, three potential problems might cause a crisis in CREI.

Firstly, the real estate vacancy rate. In that study, the international red line of vacancy rate of real estate is $5 \%$, but none of the CREI programs had vacancy rate higher than $5 \%$ before 2008. According to $\mathrm{H}$. Yang (2008): «The national vacant housing area was $127 \mathrm{mil}-$ lion square meters, which increased $2.2 \%$, compared with last year. And the vacant commercial residential buildings were 39.34 million square meters, which increased compared with last year $3.4 \% »{ }^{35}$

The second is the price-to-rent ratio, which is the ratio between the real estate price and the monthly renting price. Usually price-

\footnotetext{
${ }^{34}$ See H. Yang (2008), pp. 3-4.

${ }^{35}$ Ibidem.
} 
to-rent ratio should be between $100: 1$ to $230: 1$ (100\% to $230 \%$ ). Nonetheless, from 2005 to 2008, if we compare the real estate price index and the renting price index, the average price-to-rent ratio in 35 main cities were the following: $462.5 \%, 252.6 \%, 542.9 \%, 400 \%$, $392.9 \%$. These were much higher than the international standard. In 2005, the ratio in Shanghai and Beijing were 300\% and 360\%, which means that for recovering the cost of investment in real estate, housing owners would have to wait at least 25 years in Beijing, and 30 years in Shanghai ${ }^{36}$. This created more risks for house owners to recover their cost in the condition of bank credit backed by a fractional reserve central banking system.

The third is the price-to-income-ratio, which measures the ratio between real estate prices and the annual family income. According to international standards, if the ratio in a developed area is higher than 6, the area may suffer from a real estate bubble. In 2007, the ratio was 13.17 in Guangzhou, 11.09 in Shanghai and 13.67 in Beijing ${ }^{37}$. A fast growth of this ratio implies a significant decline in housing affordability.

\section{b) From January 2009 to February 2012 (3 years and 2 month)}

In this part, we will analyse the real estate cycle registered in China's economy from January 2009 to February 2012. As showed in Figure 3.1, the impact of monetary stimulus on CREI took a very long time to be perceived. YoYHP started to increase from $-1 \%$ in May 2009 to its peak at 13\% in April 2010. According to data available, PBOC did not inject more money after the approval of RMB4TSPP in November 2008. Rather, PBOC waited for the increase in housing prices, hoping that the economic performance will improve afterwards. In 2009, YoYCDs increased to $16 \%$, while YoYCCs declined significantly to $26 \%$. In light of these figures, credit expansion was moderate, but fostered mortgages loans somewhat.

In November 2008, YoYCDs increased 32pp to 48\% in 2010 from 2009, while YoYCCs lowered 5pp to 21\% in 2010 from 2009. The YoYHP accelerated to 13\% in April 2010 from -1\% in May.

\footnotetext{
${ }^{36}$ Ibidem.

${ }^{37}$ H. Yang (2008), p. 5.
} 
After April 2010, CREI underwent a small downturn, as reflected in the decline of housing prices. YoYHP slowed to $0 \%$ in February 2010 from 13\% in April 2010. The decline in housing prices had an impact in China's GDP and later PBOC injected more funds into the system. In 2010, the YoYCDs increased 32pp to 48\%, while YoYHP slowed 5pp to $21 \%$ in comparison with 2009 . One year later, YoYCDs increased $8 \mathrm{pp}$ to $56 \%$ and YoYCCs accelerated significantly to $102 \%$ (an increase of $81 \mathrm{pp}$ ).

This cycle had a duration of 3 years and 2 months. We also found that during this period, after declining housing prices during 2010 credit expansion was increased and this increase was noticed as credit growth rose in both developers and consumers during 2011. The monetary stimulus shored up the housing prices growth, but the economic process is not a static process, but a dynamic one, which consists of different productive stages. When interest rates are artificially low, investment increases but savings remain at the same level, thereby leading to an economic discoordination. Besides, because the value is subjective and the information is non-transferable, it is no possible for governments and central banks to know what people want to produce and consume. Therefore, monetary government intervention cause chaos in society, as it happened in CREI.

Central banking system and artificial credit expansion led to a rife malinvestment in CREI, as reflected in the evolution of the different indicators analysed during this period. According to evidence, China already have at least 40 ghost cities with houses, hotels, schools, roads and other public facilities with a very low occupancy rate. A well-known Chinese ghost city is Ordos in Inner Mongolia Autonomous Region, where the local government invested more than RMB 5bn in real estate assets ${ }^{38}$. Housing prices dropped from 1,000 RMB per square meter to 300 RMB per square meters (a decline above $70 \%)^{39}$.

But this is a part of the whole history, as CREI registered more cyclical periods, which we will illustrate in the next sections.

\footnotetext{
38 See Lu (2013).

39 See H. Zhang (2013).
} 
c) From February 2012 to January 2015 (3 years)

In this section, we will provide evidence of the credit bubble in this cycle, from February 2012 to January 2015. During this period, most ghost cities and real estate glut appeared.

After the credit binge in 2011, PBOC continued easing monetary policy during 2012, which loosened credit conditions in CREI. During this period (2011-2012), YoYCDs remained at 56\% and YoYCCs at 102\%. However, after 2013 credit growth rates in CREI slowed to $40 \%$ in the case of YoYCDs and to $49 \%$ in the case of YoYCCs. However, it is important to point out that, although the credit growth rate slowed, the credit was still growing and adding more credit in absolute terms than in previous periods.

Once the effect of the credit halted, YoYHP reached its peak at 10\% in January 2014 (but this is a lower peak than in the previous cycle, when housing prices had grown $13 \%$ ). YoYHP slowed down and reached a bottom level in September 2005, when housing prices had grown by $-6 \%$.

This cycle lasted 3 years. Comparing the duration of previous cycles, this was the shortest period up to now: 3 years and 5 months (first cycle), 3 years and 2 months (second cycle). As a result, it is fair to say that artificial credit expansion became less effective over time and the impact on housing prices has been smaller and shorter.

Meanwhile, Chinese local government debt levels reached almost RMB 25 trillion (US\$ 4 trillion) in the end of $2014^{40}$, due to stimulus measures and fiscal spending in CREI. If we take this into account, the credit bubble in the construction industry is not surprising.

According to evidence, 12 empty cities $^{41}$ sprang up in 2013, propped up by economic stimulus plans (many of them turned into ghost cities):

1. Kangbashi New Area in Inner Mongolia Autonomous Region, with a cost of RMB 5bn (\$0.8bn).

\footnotetext{
${ }^{40}$ See L. Zhang (2014) and Y. Wang (2013).

${ }^{41}$ See G. Li (2013).
} 
2. Qingshuihe County in Inner Mongolia Autonomous Region, with a total expense of RMB 6bn but became an empty city later ${ }^{42}$.

3. Bayannur City in Inner Mongolia Autonomous Region, whose cost amounted to RMB 10bn (\$1.42bn) ${ }^{43}$.

4. Erenhot City in Inner Mongolia Autonomous Region, where $93 \%$ of the houses are empty ${ }^{44}$.

5. Zhengdong New Area in Henan Province, with a total investment higher than RMB 1 trillion (\$0.16 trillion) and 55\% of the buildings are empty ${ }^{45}$.

6. Hebi City in Henan Province, with a «ghost area» similar to Kangbashi $^{46}$.

7. Xinyang City in Henan Province. Satellite pictures shows the emptiness of this area ${ }^{47}$.

8. Yinkou City in Liaonin Province, which has commercial and residential buildings of 180,000 square meters totally empty ${ }^{48}$.

9. ChangZhou City in Jiangsu Province, with commercial and residential buildings of 5 million square meters, with an occupancy rate nearly $30 \%{ }^{49}$.

10. Dantu District of Zhenjiang city in Jiangsu Province, with 20,000 houses with an occupancy rate lower than $45 \% 50$.

11. Shiyan City of Hubei Province, with residential and commercial buildings of 12.5 , with an occupancy rate lower than $75 \%{ }^{51}$.

12. Chenggong District of Yunnan Province, with a construction area of 107 square kilometers, but with a population of only 260,000 people $^{52}$.

\footnotetext{
${ }^{42}$ See CCTV (2010).

43 See F. Chen (2013).

${ }^{44}$ See R. Dai (2014)

45 See Shepard (2013)

${ }^{46}$ See NetEase.com (2013).

${ }^{47}$ See Badkar (2013)

${ }^{48}$ See China Business News (2014)

${ }^{49}$ See Cha $(2013, \mathrm{~A})$

${ }^{50}$ See Cha $(2013, \mathrm{~B})$.

${ }^{51}$ See J. Zhang (2013).

${ }^{52}$ See H. Dong and J. Zhang (2014).
} 
d) January 2015 - the middle 2016 (1 year and 6 months)

From 2014 to 2015, the YoYCDs increased 6pp to 40\%, while YoYCCs increased $9 \mathrm{pp}$ to $49 \%$. In the first half of 2016, the YoYCDs rose 6pp to $34 \%$ while YoYCDs declined 9pp to $40 \%$. As a result of credit dynamics, YoYHP arrived to a new peak in the middle of 2016. However, considering the evolution of housing prices, the new credit in CREI had less effect. During this period, not only more ghost cities appeared in China, but also some real estate enterprises went bankrupt, something that not happened in previous cycles.

In 2015, the number of ghost cities in China amounted to 50, built in the last five years and with a population density lower than 5,500 per square kilometre. The top 10 ghost cities, with a population density lower than 3,900 per square kilometre are Erenhot (Inner Mongolia Province); Alar, Beitun, Altay Prefecture (Xinjiang Province); Zhangye, Jiayuguan, Yumen (Gansu Province); Suifenhe (Heilongjiang Province); Qinzhou (Guangxi Province), Shigatse (Tibet Province $)^{53}$. Their respective provinces have a nominal GDP per capita level below 6,623 USD in 2015. Moreover, these ghost cities are well-known for the lack of protection of property rights and higher governmental intervention.

When it comes to companies bankrupcy, at least three real estate enterprises wnet bankrupt since 2015. Huaguang Real Estate, which was among the top 100 real estate companies, went bankrupt in August 2015: one of its housing program cost at least RMB 323 million, but only received back 220 million $^{54}$. On January 25, 2016, Longde Real Estate (龍德置業) went bankrupt, and faced a debt level above RMB 200 million $^{55}$. Ayeshan Real Estate (阿液山房 地產) went bankrupt on July 12, 2016, owing more than RMB 460 million ${ }^{56}$.

The 2015 Annual Report of People's Bank of China (2015中國人 民銀行年報) also admitted that the instability and uncertainty in

\footnotetext{
53 See 21so.com (2015).

54 See X. Wang (2015) and G. Liu (2015).

55 See F.Chen (2016).

56 See N. Xiao (2016).
} 
China's financial system was much higher than previously expected. The report warned that the real estate industry may be in an overheating situation ${ }^{57}$.

CREI began to recover once again in September 2015, due to interest rate cuts and stimulus measures, amid stock market crash. This stock market crash along with the stimulus measures, made investment in property comparatively more attractive, given that investment opportunities in China are limited due to capital controls.

\section{Conclusion: The risks and forecasts for China's Real Estate Industry}

As we analysed in Chapter 1, the CMFS introduces negative incentives in China's economy. The negative consequences have been felt the most in CREI. According to ABCT, the credit expansion orchestrated by government authorities has the risks of creating overcapacity and malinvestments. In the case of CREI, the case has become more evident. As we analysed in previous sections, the overcapacity is burdensome in middle-sized cities, so that the investment flows have turned in bigger cities. As a result of capital controls, government restrictions, the increase of monetary supply and the looser monetary policy from PBOC, four cycles were created in the CREI.

Notwithstanding the government intervention, the outlook for CREI is disappointing. ABCT points that the restructuring process in China's economy is still to be made, including the closure of the inefficient companies and overcapacity reduction.

As we mentioned in this chapter, CREI suffered in 2012, thereby affecting real estate enterprises both in the reduction of EBITDA and increase of debt. Moreover, the current situation of negative free cash flow generated by most companies in our data sample.

A foreseeable financial crisis and restructuring process in CREI is hard to predict exactly. However, according to our analysis, the duration of housing price expansion narrowed over time, while ar-

${ }^{57}$ See PBOC (2015), pp.12-34. 
tificial credit expansion increased, according to the evolution of M2, credit to real estate and interest rates.

According to the evidence showed throughout this paper, we consider that it is likely that following cycles in real estate industry have a shorter duration and higher intensity of falling prices (and lower intensity of increasing prices).

\section{CONCLUSION: REFORM RECOMMENDATIONS}

As we have discussed, a highly intervened CMFS and inefficient SOEs caused the challenges that China's economy faces. Unlike many people believe, even though China opened the market and real economy to foreign investment, China is still far from being a free market economy, especially in the monetary and financial field. Now we will provide some policy recommendations to resolve the problems which we discussed in this paper ${ }^{58}$.

First, China's education system should focus more on free market and property rights. Even though China implemented ambitious market reforms, absolutism is still present in public institutions and people's beliefs. A better understanding of free market dynamics and property rights is a necessary to improve the health of China's economy.

Second, we propose the privatization of SOEs, which is the main concern of China's economy. We conclude that the inefficiency of SOEs shrinks the credit availability to private enterprises and cause problems to commercial banks. Privatization of SOEs could also help China's government to concentrate on defence and justice.

Thirdly, China should abandon capital controls and fixed exchange rate policy. Capital control policy is pernicious for China's economy, as it impedes the efficient international allocation of capital. In that regard, bad investments opportunities in China would

${ }^{58}$ Our suggestions on China's reform comes from the book The Theory of Dynamic Efficiency written by J. Huerta de Soto. More information, see Huerta de Soto (2010), pp. 182-203. 
be abandoned faster, thereby disincentivizing the creation of assets bubbles and overcapacity. Moreover, the elimination of capital controls requires to remove the fixed exchange rate policy, thereby solving several problems: capital controls inefficiencies, the manipulation in $\mathrm{RMB}$, and the role of $\mathrm{RMB}$ in the international markets will strengthen when foreign investors can invest freely in China.

Fourthly, China should liberalize interest rates, privatize SOBs and gradually adopt free banking system when possible. Eliminating the limits on the interest rates for deposits and loans would be a step in the right direction, to achieve a real market in CFS. That would increase competitiveness among lenders, and depositors would receive a fair amount for their deposits, thereby reducing the subsidies to SOBs. Moreover, to achieve a real credit market in China, it will be necessary to complete the reform in the banking system and eliminate SOBs, so as to remove the influence and control of the China's government over credit. Moreover, the big bad banks or AMCs would be redundant once the SOBs have been eliminated. Later, China would adopt free banking system to avoid all the monetary and financial discoordination caused by central banking. For China, we consider that China should adopt free banking system to avoid severe economic and financial discoordination.

Fifthly, China should build an independent judicial system. An independent judicial system could avoid the collusion between the officials and entrepreneurs, and provide a fair judgment for ordinary citizens. In recent years, plenty of cases showed governmental intervention in court decisions with vested interests. National People's Congress should make laws to keep the independent judgments in the judicial system.

Sixthly, China should tweak CPC principles, allowing for principles closer to freedom and departing from Marxist ideology, following the path initiated by Deng Xiaoping. The removal of communist ideology both in the Constitution of CPC and in PRC is critical for China to achieve a real free-market and independent institutions. 


\section{BIBLIOGRAPHICAL REFERENCES}

«21so.com.» «China's 50 Ghost Cities in 2015». 2015. http:// news.21so.com/2015/hongguan_1118/1408507.html.

BADKAR, MAMTA (2013): 2 Years after that Famous Report on Chinese Ghost Cities, Things Might be Getting even Worse. Business Insider.

CHEn, Feng (2013): Local Government in Inner Mongolia Could not Pay Project Payment for Ghost Cities (內蒙古再現新鬼城: 政府拖欠百 億工程款無力支付). China Times.

- (2016): The Story after the Bankruptcy (向省委书记求助 保证 “不 跑路、不跳楼” 百强地产商 “被破产”之后). Chinatimes.com.

Chivakul, M., W., Lam, R., Liu, X., Maliszewski, W., and Schipke, A. (2015): Understanding Residential Real Estate in China. IMF Working Paper.

Coase, R., and Wang, N (2012): How China Became Capitalist. Palgrave Macmillan.

CREDIT SuISSE (2011): «Financing risks: Developers with SOE background are not inmune».

CRISIS, ZHANG, J. (2015): Inside China's shadow banking: the next subprime. n.d. CSI started facing bankruptcy, it's hard to break the freeing point in market (我国航运业破产潮起 市场极度低迷难破). Cnhangyun.com.

DAOKUn, C. (2013): A Survey on Changzhou's Ghost City（常州 “鬼 城” 真相调查: 一条马路汇集500万平方米房源). National Business Daily.

Del Amo Lamborena, J. (2012): La teoría del ciclo monetario endógeno y la economía china en 2011. Madrid: Procesos de Mercado.

Deloitte, C. (2013): The Development of Chinese Shipping Industries ( 中國航運業發展). Deloitte China.

Dong, H., and Zhang, J (2014): «Ghost City in Chengong, Kunming City after 1o-year building (昆明呈貢新區洋規劃水土不服 十年建設造出鬼城)》.

Dong, J., and NeUt, A. (2016): Global prominence of China's financial markets. BBVA Research.

Elliott, D., Kroeber, A., and QiaO, Y. (2015): Shadow banking in China: A primer. Brookings. 
EWORLDSHIP.COM. (2015):«Cumulative loss RMB 34.1 bn, the result of COASO's audit (累計虧損341億 中遠集團審計結果出爐)».

GAN, A., and Qu, L. (2010): Shipping Finance (航運金融學). Shanghai: Gezhi Press and Shanghai People's Publishing House.

GuONAN, M., and BeN S.C.F. (2002): China's asset management corporations. BIS.

HAS, J. (2013): «The secret of the mass loss and the mass layoff and pay drop in the second quarter of COSC0 (中遠巨虧隱情：二季 度裁員降薪)》. China Times.

HAYEK, F.A (1990): Denationalization of Money: The Argument Refined. London: Institute of Economic Affairs.

- The Fatal Conceit: The errors of Socialism. London: Routledge, 1988.

Hongsong Wang, W. (2014): How the Chinese Monetary Policy Influences Chinese Economy? Madrid: Universidad Rey Juan Carlos.

Huerta de Soto, J. (2006): Money, Bank Credit and Economic Cycles. Ludwig von Mises Institute.

- (2010): Socialism, Economic Calculation and Entrepreneurship. Cheltenham, Edward Elgar.

- (2008): The Austrian School: Market Order and Entrepreneurial Creativity. Cheltenham, Edward Elgar.

- (2010): The Theory of Dynamic Efficiency. Routledge.

JiANG, W. (2015): The Future of Shadow Banking in China. Columbia Business School.

LAM, B., and CORNu, S.L. (2015): QE China Style: The intentions and impacts of Chinese monetary policy easing. Macquarie.

LI, G. (2013): «China's New Ghost Cities (中国新“鬼城”)». TimeWeekly.

LIU, G. (2015): The bankruptcy of Huaguang Real Estate may become the start of the collapse of CREI (曾跻身中国房企100强的华光地产破 产了, 或拉开房企倒闭潮序幕). letscorp.net.

Lu, Y. (2013): How to make ghost cities have lights (如何讓“鬼城”亮起 來). Shanghai: International Financial News.

Mises, L. (1998): Human Action. Ludwig von Mises Institute.

- (1957): Theory and History. Ludwig von Mises Institute.

NetEase.Com. (2013): See a New Ghost City Built in Hebi, Henan（河 南鶴壁新區人煙稀少 成新 “鬼城). NetEase.com. 
PBOC. (2016): «Annual Report of PBOC 2015 （中國人民銀行2015 年報)».PEI, Y. (2016): The bankruptcy of CSI is approaching because of the downturn of shipping industry (受累航運低谷 造船業破產潮 臨近). China Business Journal.

Poor County spent RMB 6 Bn on Building a New City (內蒙貧困縣60 億建新城續:民眾不吃喝需4年還息). People's Daily, 2010.

RAIFENG, D. (2014): China will Have 50 Ghost Cities According to Data (数据揭密 陆将出现50座鬼城). Taipei: China Times.

RuAN, M. (2009): The 30-year Empire of Deng Xiaoping (鄧小平帝國 三十年). Taipei: Yushan Publishing House.

SeBWEeKLy (2016): The COSCO Shipping Corporation you do not know (你所不知道的中國遠洋海運集團). hsdhw.com.

See Yinkou, a New Ghost City (辽宁营口也变“鬼城” 18 万 m² 小区零入 住). China Business News, 2014.

Sheng, A., NG, C.S., and Edelmann, C. (2013): Asia Finance 2020: Framing a New Asian Financial Architecture. Oliver Wyman.

SHEPARD, W. (2013): A Journey to China's Largest Ghost City. Global Chronicle.

SHIPPINGCHINA (2015): «No bottom line: SOEs loses money in shipping market but still grabbing the market even facing losing money (完全沒有底線: 航運國企虧本搶市場甚至零運費)》. Chinaports.com, 2015.

SINA.COM (2013): How to make ghost cities? (“鬼城”是怎樣煉成的), . Sina.com.

StOCKECHANGE, Reading the Chinese. n.d.

Sun, C. (2014): SOSEs would try to become mixed-ownership companies (航運國企將實行混合所有制改革). 21st Century Business Herald.

Sun, L. (2015): «CSC loses RMB280 millions, the winter of CSI continues (中海集运预亏28亿元 航运业寒冬延续)». China Business Journal, 2015.

The ECONOMIST (2013): «The Shibor shock». The Economist.

Torras, L. (2013): El despertar de China. Instituto de Estudios Económicos.

TrivedI, A. (2016): «Why China's Bad Banks Needs Another \$5 Bn.» The Wall Street Journal.

Vegas García, A. (2013): La sombra de la prosperidad china. Madrid: Universidad Rey Juan Carlos. 
Vogel, E. F. (2011): Deng Xiaoping and the Transformation of China. Cambridge, Belknap Press of Harvard University Press.

Walter, C., and HowIE, F. (2011): Red Capitalism: The Fragile Financial Foundation of China's Extraordinary Rise. Singapore: John Wiley \& Sons Singapore.

WANG, W. (2015): Three bankrupted in one month CSI is facing the worst situation in the last 30 years (一個月破產三家 航運業三十年 來最糟). Jiemian.com.

WANG, X. (2015): The Top 100 Huaguang Real Estate is facing bankruptcy (全国百强常州华光地产遭破产清算 多楼盘烂尾). Beijing: People's Daily.

WANG, Y. (2013): The Warn on New Cities Plans from Chinese Central Government. EnnWeekly.

XIAO, F., and KimbalL, D. (2005): Effectiveness and Effects of China's Capital Controls. China \& World Economy.

XIAO, N. The Myth of the Bankruptcy of Ayeshan Real Estate (山東日 照: “僵屍企業”阿掖山房地產破產之謎). ifeng.com, n.d.

XIAOPING, D. (1993): «Volume 3 of Selected works of Deng Xiaoping».

YANG, H. (2008): The Study of the China's Real Estate Bubble and the Solutions (我國房地產泡沫研究及應對措施). house.china.com. cn.

YANG, J. (2015): «If Maersk Lays off Employees, What Will COSCO and CSC Do (馬士基都裁員了, 中遠中海的裁員還有多遠?). ship. sh.

Zhang, H. (2013): «The Ghost Cities in China» (中國的一座座鬼城) . Apple Daily.

ZHANG, J. (2013): The Ghost City in Shiyan, Hubei Province (湖北十堰 现“鬼城”鬼影住房空置率畸高). China Business.

ZHANG, L. (2014): Chinese Local Government Debt Crisis and Opportunity (中國地方政府債務危與機). London: Financial Times Chinese.

ZHANG, (2015): «The Predestination of China's Shipping Industry» Wallstreetcn.com, (2015).

ZHANG, Y. "When CSI is in such a hard time, the senior executive of COSCO and CSC are raising up their own salaries (海運業日 子過得這麼艱難 中國遠洋和中海集運的高管們還大幅加了薪).” Jiemian.com, (2016). 
ZHu, J. (2012): From Laissez-faire to Monopoly, The Monetary Economy of China - Past and Present (從自由到壟術 中國貨幣經濟兩千年). Taipei: Yuan-Liou Publishing, (2012). 
